\title{
"Mitä piilee yrittäjyyttä painottavien kasvatustavoitteiden takana?”
}

\author{
Tohtorikoulutettava Hanna Laalo, 31, tarkastelee kriittisesti \\ akateemista koulutusta uudistavaa yrittäjyyseetosta.
}

MINUSTA TULI TUTKIJA, vaikka poiketen monista kollegoistani en opiskeluaikanani tähdännyt tälle uralle. Valmistuttuani kasvatustieteen maisteriksi vuonna 2012 ajauduin töihin yrittäjyyden projektitutkijaksi Turun yliopiston kauppakorkeakouluun. Uusi ympäristö avarsi ajatteluani, mutta aloin pian kaivata tutumpien aiheiden pariin. Aloitin tohtorikoulutettavana kasvatustieteiden laitoksella vuonna 2015. Vuosien mittaan itsenäinen ja pitkäjänteinen tutkijan työ on alkanut tuntua yhä enemmän omalta.

Luin aikuiskasvatustiedettä sivuaineena ja suuntauduin pedagogisissa opinnoissa aikuisopetukseen. Alan tutkimuksessa minua kiehtovat poikkitieteellisyys ja monipuolisuus, joiden avulla ihmistä ja aikuisuutta on mahdollista katsoa ja ymmärtää monelta kantilta.

Tutkimuksessa minua vetävät puoleensa asiat, joista ärsyynnyn, esimerkiksi elämäntaito-oppaiden ja -valmennusten kapeat ja normatiiviset tulkinnat siitä, kuinka elämää tulisi elää. Ärsytyksestä kumpusi myös väitöskirjaani innoittanut kiinnostus yrittäjyyskasvatuksen yltiöpositiivisuuteen ja piilevään poliittisuuteen.

JOS EN TUTKISI, työskentelisin toimittajana. Olen moneen suuntaan utelias, ja etenkin politiikka ja

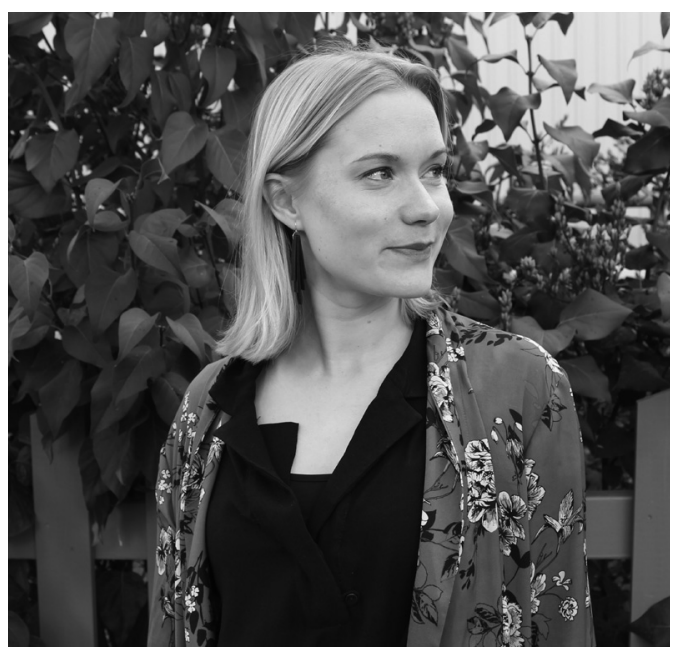

Hanna Laalo hoitaa tohtoriopintojensa ohessa Aikuiskasvatuksen Tutkimusseuran tiedottajan pestiä.

kulttuuri kiinnostavat. Tarkkailen maailmaa mieluiten sivusta, mutta toivon, että töistäni olisi hyötyä ja iloa muille kuin itselleni. Kieleen ja kirjoittamiseen suhtaudun intohimoisesti siitäkin huolimatta, että kirjoittaminen on minulle useimmiten hidasta ja vaivalloista. 


\section{YRITTÄJYYDEN EETOS AJAA IHMISET JATKUVASTI}

TARKKAILEMAAN JA TYÖST $\ddot{A M} \ddot{A} \ddot{A} N$ ITSEÄ̈̈N.

AIKUISKASVATUSTIEDETTÄ TARVITAAN yhteiskunnassa pitämään yllä kriittistä tietoisuutta, edistämään tasa-arvoa ja puolustamaan humanismia. On huolestuttavaa, että egoistisesta ja viileän rationaalisesta ajattelusta on tullut yhteiskunnassamme tavallista ja luonnollista, samalla kun siitä poikkeaminen saatetaan leimata naiiviksi idealismiksi tai epäonnistumiseksi. Kun huomio on yksilöiden välisessä kilvoittelussa, on vaarana, että ihmiset käyttävät elämänsä loputtomaan itsensä optimointiin solidaarisuuden kustannuksella.

PARAIKAA TUTKIN, miten yrittäjyys asettuu yliopistokoulutuksen eettiseksi ohjenuoraksi määrittelemään akateemisen koulutuksen tarkoitusta ja opiskelijoiden käsityksiä itsestään.

Koulutuspoliittisten päämäärien taustalla on aina arvolatautuneita olettamuksia ja valtapyrkimyksiä. Niitä on tarpeen analysoida kriittisesti, koska kyseenalaistamatta omaksutuilla ajattelutavoilla saattaa olla arvaamattomia käytännön seurauksia. Koulutuksessa ja kasvatuksessa yrittäjyyden eetos ei merkitse ainoastaan yrittäjyysuralle valmistamista vaan myös sisäisesti yritteliäiden kansalaisten kasvattamista. Lupaamalla, että menestys on valinta ja itsestä kiinni, se ajaa ihmiset jatkuvasti tarkkailemaan ja työstämään itseään. Tällaisen ajattelun on arvioitu altistavan neuroottisuudelle, riittämättömyyden tunteille ja uupumukselle.

ESIKUVANA PIDÄN tutkijoita, joilla on profiloitumispaineista huolimatta pokkaa rikkoa rajoja, poiketa valtavirrasta ja innostua uusista ilmiöistä. Väitöstutkimukseni keskeisiä innoittajia ovat olleet Ulrich Bröcklingin ja Nikolas Rosen kirjoitukset yrittäjäminästä, Miikka Pyykkösen yrittäjyyden eetoksen analyysit, Esko Harnin kriittiset ja omaperäiset yrittäjyyskasvatustutkimukset sekä Katri Komulaisen, Seija Keskitalo-Foleyn, Maija Korhosen ja Sirpa
Lappalaisen toimittama teos Yrittäyyskasvatus hallintana (Vastapaino 2010). Hallinnan näkökulma yrittäjyysajatteluun ja yrittäjyyskasvatukseen mahdollistaa normatiivisten olettamusten haastamisen ja toisenlaisen todellisuuden ja toimijuuden tunnustelun.

SEURAAVAKSI HALUAISIN PEREHTYÄ sosiologiseen tekstien ja kirjallisuuden tutkimukseen ja analysoida esimerkiksi yrittäjäminän vastatulkintoja nykykirjallisuudessa. Myös nuorten aikuisten kokemien menestyspaineiden ja selviytymiskeinojen tutkiminen narratiivisella ja etnografisella tutkimuksella kiinnostaa. Ideat ovat vielä hataria, koska ajatukset ovat intensiivisesti väitöskirjan loppuunsaattamisessa.

KOLLEGOILTANI SAAN oivalluksia, jotka nostavat omani uudelle tasolle. Kirjoitusprojektit erilaisten ja eri alojen ihmisten kanssa ovatkin työssäni antoisimpia. Pidän tärkeänä, että voin jakaa työkavereiden kanssa yliopistotyön turhautumista ja juhlistaa harvoja tähtihetkiä, kuten apuraha-arpajaisvoittoja. Laitoksemme ikioma big band KasvaBeat tuo piristystä toisinaan ankeaan akateemiseen arkeen.

KUN EN TUTKI, luen kaunokirjallisuutta, käyn teatterissa, kirjoitan lyhytproosaa pöytälaatikkoon ja juoksen. Arvostan suuresti vapaa-aikaa, ja siksi pyrin viettämään illat ja viikonloput töiden sijaan muiden kiinnostavien asioiden ja tärkeiden ihmisten parissa.

\section{Klassikko, johon palaan}

Hayao Miyazakin Henkien kätkemä teki aikoinaan lähtemättömän vaikutuksen ja on minulle edelleen tärkeä elokuva. Kuten muutkin Miyazakin fantastiset animaatiot, se on nerokas, humoristinen, haikea ja lohdullinen - parasta mahdollista ruokaa mielikuvitukselle!

Sarja vie aikuiskasvatuksen tutkijan arkeen ja verkostoihin. Sen tuottaa Aikuiskasvatuksen Tutkimusseura. 